\title{
The Importance of Theater Pedagogy from a Student's Perspective. An Empirical Study in a German-Speaking Elementary School in Romania
}

Mirona Stănescu, Daniel Andronache 


\title{
The Importance of Theater Pedagogy from a Student's Perspective. An Empirical Study in a German-Speaking Elementary School in Romania
}

\author{
Mirona Stănescu ${ }^{a}$, Daniel Andronache $* b$ \\ ${ }^{a, b}$ Faculty of Psychology and Educational Sciences, Babeș-Bolyai University, 7 Sindicatelor Street, Cluj-Napoca, 400029, Romania \\ *Corresponding author: daniel.andronache@ubbcluj.ro
}

\section{Abstract}

Keywords:

theatre pedagogy, education, personal development, social development, aesthetic development
Could school and theater be seen as a symbiosis? The roots of the school theater go back to the 15th century. Early on, the educators recognized the importance of drama for the development of the students. But what do the students think about the theatrical education for their own development?

This paper presents the results of a qualitative research designed to explore the role of education through theater for the personal, social skills and aesthetic development of the students. For this purpose, a semi-structured interview was used. In our qualitative study we examined the effects of theatre education from the perspective of the students. We interviewed 20 primary school students of the German-speaking school in Cluj-Napoca, who had theater pedagogy as optional courses for four years about their personal experience with theatre. Results demonstrate the development of personal, social and aesthetic skills. The data obtained show that students themselves recognize the significant and positive impact of the education through theatre regarding the emotional, social and aesthetic development (as components of personal development), and the relationship between them.

\section{Zusammenfasung}

\section{Schlüsselworte:}

Theaterpädagogik, Bildung, persönliche Entwicklung, soziale Entwicklung, ästhetische Entwicklung
Können Schule und Theater als Symbiose gesehen werden? Die Wurzeln des Schultheaters reichen bis ins 15. Jahrhundert zurück. Schon früh erkannten die Pädagogen und Pädagoginnen die Bedeutung des Theaterspiels für die Entwicklung der Schüler und Schülerinnen. Aber was denken diese selber über die Theaterstunden für ihre eigene Entwicklung?

Die vorliegende Arbeit präsentiert die Ergebnisse einer qualitativen Forschung, die die Rolle der Theaterpädagogik für die persönlichen, sozialen Fähigkeiten und die ästhetische Entwicklung der Schüler und Schülerinnen untersucht hat. Zu diesem Zweck wurde ein halbstrukturiertes Interview verwendet. In unserer qualitativen Studie haben wir die Auswirkungen der Theaterpädagogik aus Sicht der Schülerinnen und Schüler untersucht. An der Studie nahmen 20 Grundschülerinnen und -schüler der deutschsprachigen Schule in Cluj-Napoca/ Rumänien teil. Diese hatten vier Jahre lang Theaterpädagogik als Wahlfach und wurden über ihre persönlichen Erfahrungen mit dem Theaterspiel befragt. Die erhaltenen Daten zeigen, dass die Probanden selbst die signifikanten und positiven Auswirkungen der Theaterpädagogik in Bezug auf die emotionale, soziale und ästhetische Entwicklung (als Bestandteile der persönlichen Entwicklung) und deren Beziehungen untereinander erkennen.

\section{Introduction}

During the last 30 year the value of drama classes within the Romanian schools has recorded increasing appreciation. More and more teachers, especially primary school teachers, are using methods of theatre pedagogy in their classes, because they recognize the potential of playing theatre and acting. And yet the official recognition of the performing arts classes in general and the drama classes in particular at ministry level is sidelined and the official introduction of theatrical education in the national curriculum has never taken place. In many schools the theatrical art can be found only as an optional course, offered under different names.
The present article presents the results of a qualitative research designed to explore the role of theatre pedagogy for the personal, social skills and aesthetic development of the elementary school students from their perspective. Also, this work is intended to be a plea for the official introduction of theatrical art in the national curriculum for undergraduate schools.

The new educational policies and priorities aim to place the students at the centre of its own learning. The childcentred approach prioritizes the child's emotional needs over the mere requirement to absorb knowledge and facts. Children are seen "as unique individuals" (Jones, 2003, p. 54) and learning has to be "the product of the active relationship between individuals and the environment" (Jones, 2003, p. 54). 
In Great Britain The Newsom Report acknowledges the role and the place that the arts should have in the school curriculum. In their opinion, the arts can help children "to come to terms with themselves more surely than by any other route" (***, 1967, p. 157). Jensen points out the importance of dramatic arts for supporting the development of the students: "The real driving force behind dramatic arts is what it does for the emotional, physical, and cognitive abilities of the student" (Jensen, 2001, p. 76)

The playful character of the theatre enables the students to live out their fantasies, to transgress their own biographical boundaries and to transform and present themselves in an artistic space of freedom. Theater is not just fiction and games, but also a real experience. Theatre always implies the presence of the public, who relate to the theater play through their own perception of reality and own associations and interpretations. Thus, in addition to the art of acting, the art of watching is very important. By investigating the world through play and through active approaches, the children understand the world both rationally and emotionally. Theater education with a focus on aesthetics includes watching and learning theatre techniques and forms and students learn to experiment with different theatrical expressions. It is about a combination of personal, social and aesthetic processes.

\section{Theoretical foundation}

\subsection{Theatre pedagogy}

Theatre Pedagogy (in German "Theaterpädagogik") is a discipline that combines both theatre and pedagogy. Through the paradigm shift of the $80 \mathrm{~s}$, the aesthetic and artistic qualities are placed at the center of the reflection of theatre education. Theatre pedagogy has developed separately from school theatre and drama education. Its main distinction is the integration of both art and education to develop personal, social and aesthetic competences of the students. The focus of the drama education is on the learning of performance and emphasizes the process of playing, without highlighting the theatrical-artistic moments, but theatre pedagogy goes beyond the notion of play and focuses on the "aesthetic perception and production in the sense of the theater in its narrower, especially acting-artistic form" Vaßen, 1997, p. 64). The theatrical processes, the aesthetic experiences and the experiences of the players are taken into account to the same extent.

The theatre pedagogy subsumes - as the name implies both theatre and pedagogy. These include, besides the pedagogical concepts, the artistic aspect of theatre and its aesthetics. Belgrade even claims that education without these skills remains "ignorant" and the theater without pedagogy remains "commonplace" (Belgrade, 1997, p. 107). For this reason, not only the pedagogical conceptions are important for the theatre pedagogy, but also it demands a confrontation with theories of acting.

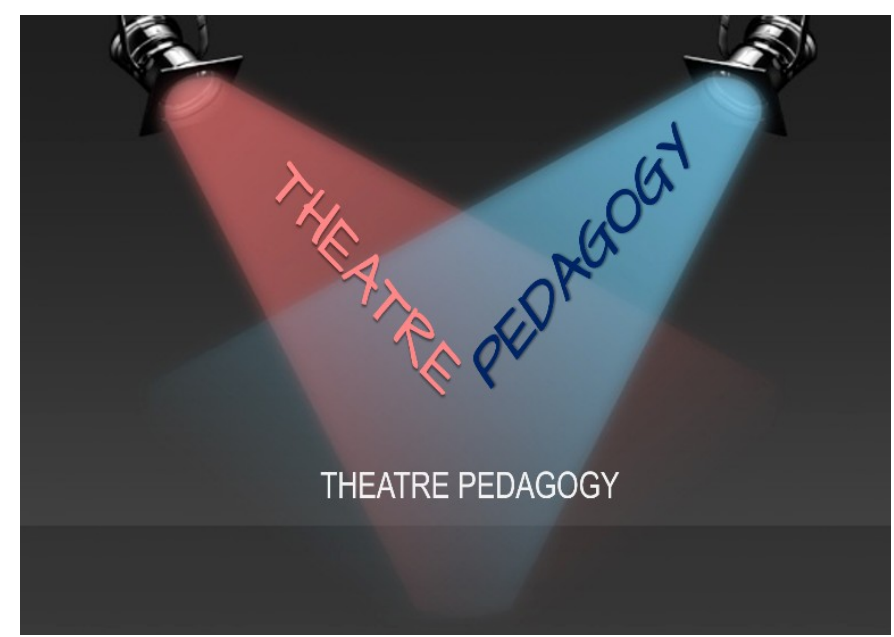

Figure 1. Relationship between theatre and pedagogy (Stănescu, 2012, p.15)

Theatre pedagogy focuses on the initiation of learning and experience processes through theatre. The basis of the theatre pedagogy is the holistic approach that tries to see people in all their dimensions and life contexts. The human being is understood as a unity of mind, body and soul, which is why all three areas are addressed and promoted.

\subsection{Personal, social and aesthetic development: theoretical approaches}

Many drama theorists (Ritter, 1987; Nickel, 2005; Czerny, 2004) regard the role play as having the potential to develop the personality of the player, and at the same time offers the possibility for cross-curriculum work.

The main purpose of theatrical work with students is the personal, social and aesthetic education of students, as revealed by 40 years of published work. In particular, Czerny (2004) took this into account in her theatrical 
didactic model SAFARI. According to Czerny, theatre pedagogy leads to a personal, social and aesthetic development of the players, because it not only enhances the individual self-shaping abilities, but also develops the aesthetic consciousness and appeals to social responsibility. In Czerny's theatrical model, the three educational aspects mentioned are not treated separately, but they are understood as a whole.

\subsubsection{Personal development}

At the centre of the theatrical process is the student. Fundamental for the theatrical work is the acceptance of one's own personality and the assessment of one's own abilities. The students learn to consciously perceive their own ego, get to know their possibilities and limits, with the goal to train their "I-the actor" ("Spieler-Ich"). The process of personal development unfolds when paying attention to each student's perception, imagination, emotion and movement. Personal development is achieved only once the students become aware of these abilities, when they relate those to previous perceptions and sensations, and can interpret them.

\subsubsection{Social skills development}

For a better understanding of the importance of acting for the development of the social skills of the students, we should determine what we mean by "social skills". There are numerous definitions, but for our purpose we take into consideration those of Hersen and Bellack (1979), of Phillips (1978) and of Libet and Lewinsohn (1973).

Hersen and Bellack (1979, p. 169) state that "social skills are interpersonal behaviours which are normative and/or socially sanctioned".

Phillips (1978, p. 13) defined social skills as "the extent to which he or she can communicate with others, in a manner that fulfills one's rights, requirements, satisfactions, or obligations to a reasonable degree without damaging the other person's similar rights, satisfactions or obligations, and hopefully shares these rights, etc. with others in free and open exchange" .

Libet and Lewinsohn (1973, p. 304) defined social skills as "a complex set of behaviours making up the ability both to emit behaviours which are punished or extinguished by others".
Although many authors are using the concepts "social abilities", "social skills" and "social competence", there is a difference between them. Jovaiša (1993) (apud. Jurevičiené, Kaffemaniene,, Ruškus, 2012) and Lepaitè et al. (2003) (apud. Jurevičienė, Kaffemanienè, Ruškus, 2012.) show different stages in the formation of any act, the lowest stage being the ability, while the highest being the skill. The capacity to apply the social skills represents the social competence (Lepaite et al 2003). Social skills are part of a superordinate construct: social competence. Whereas social skills are generally viewed as being specific behaviours or activities that lead to desired social outcomes, social competence is a summary term based on judgement from others reflecting how a person's implementation of social skills is viewed in terms of adequacy (Merrel \& Gimpel).

Gresham, Sugai and Horner (2001, pp. 333-334) classifies social skills in five dimensions:

- peer relations skills,

- self-management skills,

- academic skills,

- compliance skills

- assertion skills.

The social skills are relevant only when individuals are part of a group. That is why the ensemble playing in theatre pedagogy is essential. The students are not only confronted with their own perceptions, feelings, ideas and thoughts, but also with those of their fellow players. The encounter, as well as the confrontation with the other players, requires not only empathy, but also the ability to cooperate throughout the playing process. Social education can emerge when commitment, solidarity, coming together, tolerance and acceptance of the other's opinion and person can be taken for granted in the theatre play.

\subsubsection{Aesthetic development}

Aesthetic education has an important role in the current theatre pedagogical discussion. The term aesthetics (aesthesis) comes from the Greek and means "sensory perception". In everyday language, the term "aesthetical" is used as beautiful, which is understandable when one considers that aesthetics has long been understood as the theory of the beautiful. However, Kant changed this point of view because the focus of his aesthetic theory is not only on the traditional category of the beautiful but also on the category of the sublime. It is judged as beautiful that 
which creates a feeling of pleasure in the subject, although it is neither useful nor morally correct and it triggers an interesting pleasure. In line with Kant's theory of aesthetics, Friedrich Schiller posed for the first time the theoretical question of the meaning of art and artistic activity in his book About the Aesthetic Education of Man, published in 1795.

In today's discussion about aesthetic education, two categories are recognized: (1) the perceptive and creative examination of art and (2) the sensitizations of the senses when dealing with every day and designed offers of perception.

For our work, Henschel's (2000, p. 13) understanding of aesthetic education is considered, e.g. that aesthetic education is understood as the "engagement of the subject with itself in the medium of art", because the focus is on the process of theatre play by the layperson.

But what are the special qualities of theatre in the process of educating students?

A special feature is the double role presence, that of actor and character. According to U. Henschel (2000), "standing in between" is characteristic of the relationship between player and character.

Even in the transformation from actor to character, the areas of self-development become effective in order to empathize with other people and situations. If selfdevelopment is primarily about experiencing oneself, playing theatre is about experiencing as a character. The aim is to acquire "foreign" experience which should enhance the processing and expressing of one's own and other experiences in such a way that it can become public. In this area of aesthetic education, it is especially important to make one's own experiences usable for the transformation into figures. The impersonation of a character also allows exploring and staking of personal boundaries. In this phase, the actors have the opportunity to experience themselves in a character or another and to discover the many forms of the "I". In the space between what is and what might be, your individual "scope" unfolds. This scope also enables the student to be authentic because they can always redesign their identity.

\section{Research methodology}

\subsection{Participants}

A number of $\mathrm{N}=20$ participants were involved in our research, students in the same class at the German School "George Cosbuc", Cluj-Napoca, Romania, where every subject is taught in German, although the mother tongue of the students is Romanian. All the subjects took part in the optional course of theatre pedagogy for four years, between 2015-2019. Their average age at the time of the interview is $M=10$ years old, and all of them come from urban areas.

Because of the long period of time we worked with the students, we managed to build and maintain a close relationship, based on trust, which encouraged the students to be very honest in their answers.

\subsection{Research design and procedure}

The hypotheses of the study was the following: Theatre education has a positive impact on the emotional, social and aesthetic development of the students.

To explore the role of education through theatre for the personal development of the students, a qualitative research design was developed, aiming to identify the relationship between the emotional, social and aesthetic development. As Creswell (2013) points out in a qualitative research, the researcher does not bring a preconceived notion of the result, but the participants share their experience and their perspectives. The flexible format of a qualitative research "permits open-ended interviews, if properly done, to reveal how (participants) construct reality and think about situations, not just to provide the answers to a researcher's specific questions and own implicit construction of reality" (Yin, 2012, p. 10). Because qualitative researchers do not rely on one single data source (Creswell, 2013; Yin, 2012), we collected data also from a questionnaire and from our own observations. We developed and used a semi-structured interview aiming to evaluate the level of emotional, social and aesthetic development of the subjects. Note that the construct validity of the interview protocol was assessed by two independent experts from the Faculty of Psychology and Educational Sciences, Babes-Bolyai University of Cluj-Napoca, Romania.

The data obtained were qualitatively and descriptively analysed, categorising the answers, following in-depth probing and questioning subjects based on their responses, but also understanding their motivation and feelings. 
The interviews were conducted individually, lasted about 30 minutes and the participants were explained that their participation in the study is voluntary. The researcher was the one who organized and conducted the interviews.

All interviews were recorded with a mobile phone with no external microphone. The advantage of this device was that the respondents did not feel disturbed or intimidated by large equipment. The transfer to the computer was possible without loss of voice quality, so that hardly any unclear places or dubious statements emerged during the transcription. All interviews were transcripted by the researchers without noting the non-linguistic expressions and voice modulations (louder/quieter, faster/slower, higher/lower) and pauses.

We accept that the complexity of the answers may have been affected by the fact that the interview was done in German and not in their mother tongue.

\section{Results and Discussions}

Following the analysis of the interviews, the answers were centralized, and three main categories were formulated: (1) personal development, (2) social skills development and (3) aesthetic development.

\subsection{Personal development}

Due to the complexity of the answers, this category was divided into four other subcategories:

- self-confidence and self-esteem,

- self-expression and self-reflection,

- expression managing and regulating of emotions,

- learning German (as foreign language).

\subsubsection{Self-confidence and self-esteem}

I learned to get to know myself. (M.F.)

Within this subcategory the students referred to aspects such as: speaking in front of an audience, self-confidence and self-esteem. From the answers given and our observations along the four years it was found that students have experienced increased self-esteem and selfconfidence due to the participation in the optional course "theatre pedagogy".

Among the most important moments and aspects of the four years of the course, students often mentioned the improvisation games, which gave them the opportunity to learn to trust their first instinct. At the same time, they were put in a position to accept the challenge of playing and presenting themselves in front of a smaller audience (in front of their classmates) as well as in front of a wider audience (parents, teachers, friends). As a consequence of students having to perform in front of a larger audience arose the ability to speak in public. For the theatre performances, the students had to memorize some lines and tell them in front of the audience, which made them feel important and proud of themselves.

From our own observations it became apparent that after four years of theatre pedagogy, students were more confident in expressing their own thoughts and ideas. The appreciation of the others contributed to the proliferation of positive experiences, so it gave confidence to all the students, especially to the shy ones, who became aware of their value and strengths.

Self-esteem is an intricate part of a healthy psychological development (Bandura, 1997) and it can be defined as the extent to which one values themselves (Blaskovich \& Tomaka, 1991). Self-esteem and selfconfidence affects how students perform academically, emotionally, and socially (Scott, 2011). Introducing theatre pedagogy into the school core curriculum we could encourage students to be more self-aware, to enhance their self-esteem and to have more self-confidence.

\subsubsection{Self-expression and self-reflection}

I learned how to express myself better. (A.H.)

For the subcategory "self-expression and selfreflection", students talked about discovering new methods and abilities for expressing themselves and about presenting what they had learned and accomplished in front of the others.

During the interview some of the students mentioned that they learned to reflect on their own work and their feelings about the work of the others. The reflection accompanied the entire work process, because at the end of each theatre lesson there was a reflection phase in which the students were encouraged to think and to verbalize their whole experience. This allowed them to detach themselves from their individual perception and feelings, so that new experiences could arise. The new experiences lead to a new perception of reality. According to Scheller (1998, pp.18-19), experiences arise when one processes an experience in the sense of a reaction to a 
situation in which one is physically, emotionally and intellectually involved.

The theatre art form is one of the purest forms of selfexpression. It has been demonstrated that theatre education has an impact on students, both academically and socially (Deasy, 2012). By playing theatre students are likely to be more self-aware and more expressive. Also, they are more reflective, so they increase their awareness of their strengths and abilities. "We define selfexpression as expressing one's thoughts and feelings, and these expressions can be accomplished through words, choices or actions. " (Kim \& Ko, 2007, p. 325).

\subsubsection{Expression of emotions and emotional awareness}

I've learned to show feelings that I don't feel at the moment. (M.T.)

Social life requires diverse and differentiated skills and abilities in the emotional-social area, such as respecting the wishes and needs of other people or helping each other. Goleman defines Emotional Intelligence as "the capacity for recognizing our own feelings and those of others, for motivating ourselves, and for managing emotions well in ourselves and in our relationships." (Goleman, 1998, p. 316). According to Goleman there are five components of emotional intelligence:

- self-awareness,

- motivation,

- self-regulation,

- empathy

- adeptness.

The students talked in the interviews about being able to express their feelings and emotions and dealing with them better after the drama class. Also, they spoke about other aspects of emotional awareness, such as: being less shy, being aware of their own emotions, having the courage to express their emotions and adapting the expression of their feelings to different situations.

From our own observations, we managed to determine that the students were able to release internal blockages, learn new truths about themselves and exceeded their own limits. They were also more willing to express their feelings and thoughts.

Theatre pedagogy allows students to experience the expression of different emotions and reflect about them.
By playing different roles the pupils can recognize not only the emotions of the character but also their own. Emotional intelligence requires not only to recognize your emotions, but also to be able to regulate and manage them. Drama needs teamwork. That means that the players need to work with each other and to interact with each other. They have to understand their own emotions as well as the emotions of others and how to interact and communicate with each other.

\subsubsection{Learning German (as foreign language)}

As a character I could speak in German without fear that I would say something wrong, because it was not I who made the mistake but my character. (T.P.)

The interviewed students attend the German schools for the German minorities. However, $85 \%$ of them are Romanians and Hungarians and they don't have German speakers in the family. As such the only contact with the language of study is at school.

In order to learn a foreign language, you need one thing above all: oral language practice. Language is used specifically when speaking. When talking to other people, language has an immediate effect on the audience and the speakers feel that they have an impact. The didactic approach focused on meaning complements the traditional and systematic teaching of a foreign language, which mainly turns to the written language and is therefore primarily oriented towards formal and structural aspects of the language. In drama classes communication and pragmatic language use are in the foreground, creating speaking opportunities in action-oriented, situational, natural and targeted contexts in which the learners can activate and apply their theoretical language knowledge. In addition, the necessary pragmatic means, and strategies are conveyed in order to develop the ability to communicate spontaneously with a conversation partner.

The language skills of the students were greatly improved as a result of the drama course, an aspect noticed both by the students and the instructor. The students gradually progressed from responding during the reflection phase entirely in Romanian (although spoken to in German), to expressing complex feelings and emotions freely and entirely in German. Moreover, they were confident enough to contribute to the development of the dramaturgy and to write the lines. For every performance the students wrote the dialogues by themselves. 


\subsection{Social skills development}

This class was about me with myself and with the others. (E.B.)

As described above, social skills are needed by individuals to interact and communicate with each other and are essential in building relationships and to adapt to social situations. Social skills are components of the social behaviour.

When asked to report the impact of the theatre class on their social skills development, the students mentioned the following ideas:

- teamwork

- making new friends

- sharing important tasks with colleagues

- sharing joy with colleagues

- empathy

- the importance of the group as a whole

- reaching a consensus

- everybody is equally important

- I am not the centre of the universe

- everybody is involved in the same thing

- the good organisation in the group.

This mentioned social skills can be summarized into following categories.

- cooperating and negotiating with others,

- initiating and maintaining friendships

- solving problems,

- understanding the needs and feelings of others,

- articulating one's own needs and ideas,

- expressing their own emotion.

According to our observations during the four theatre project years, we can say that as a result of the drama classes the pupils were more willing to work and cooperate with each other. Also, the teacher of the class confirmed our observation: the students were working better with each other during the other classes and they were playing much more often group games during breaks.

\subsection{Aesthetic development}

On stage I am another person. And I may like or dislike this person, but I have to understand him/her.

(S.P.)
Theatre pedagogy is also one of the areas of aesthetic education. According to Czerny (2004), theatre pedagogy promotes aesthetic awareness and develops aesthetic behaviours: attention, wonder, openness, synaesthesia and conscious sense of time. The goal is to promote selfunderstanding and understanding of others by empathizing, introducing and imagining the characters. Both the "I-the actor" (Spieler-Ich) and the "I-the character" (Figuren-Ich) are important components of acting, because the experiences of the "I-the actor" flow into the game of the "I-the character". Czerny (2004) notes that the subjective experiences do not "get stuck" in the area of self-experience but are objectified by the played character.

In the interviews the students talked about their feelings impersonating a character. They observed that by immersing themselves into the character, they could better understand different kinds of thinking and acting in various situations. They were better equipped to understand themselves and others through empathy and mental transfer into a character.

For the students it was particularly important to have the opportunity to observe each other during the improvisation exercises. Czerny (2004) also highlighted the importance of improvisation in allowing the students to discover and promote their own creativity and imagination. The players had the opportunity to improvise spontaneously based on a topic, text or figure, without fear of "embarrassing criticism from a foreign audience" (Weintz, 2008, p. 197), because the participants are both actors and spectators. During the improvisation exercises the students encountered both sides of aesthetic experience: the role of the actor and the role of the audience. This is an important aspect of the theatre pedagogy because the spectators "become co-discoverers, co-inventors, co-creators of the action" (Weintz, 2008, p. 175). The active role of the viewer demands that he "remains open in perception, sees connections, correspondences and information in completely unexpected places, which makes the previously discovered appear in a completely different light." (Weintz, 2008, p. 175)

At least some of the students were able to identify the differences and similarities between the professional theatre and their own form of theatre, and the whole experience changed the way they perceived theatre performances of professional actors and asked themselves 
where the directors got their ideas from, how the actors learned their lines, how they decided which costume they should wear.

The reading and deep understanding of these literary texts and the accomplishment of creating their own adaptations of these texts for the stage, contributed to the aesthetic development of the students. The 4 literary texts with which they worked during the project are: "The Queen of Colours" by Jutta Bauer, "Where the Wild Things Are" by Maurice Sendak, "Aladdin and the Magic Lamp" from the Arabian Nights, "The Little Prince" by Antoine de Saint-Exupéry. The 4 texts were adapted and presented in front of a larger audience at the end of every school year.

\section{Conclusions}

As a result of enrolling in the theatrical education course, the students developed from a personal, social and aesthetic point of view. So, taking into consideration the results described above, we can say that our hypothesis was confirmed.

The theatre classes encouraged the students to explore and experiment with the different forms of body motion, movement, speech and expression in a structured and secure environment. At the same time, they were trained to recognize their own emotions and the different ways to express them.

As actors in a theatre play, the students embark on aesthetic processes with their whole being. They experienced human situations in another "reality" that reflects their own world like a mirror. In this "other world" the pupils were able to express themselves with body, language and facial expressions and transform themselves in different ways. Through reflection, they were able to better understand their own world, their own actions and the actions of their peers.

In particular, the positive effects upon the students' self-confidence should be emphasized: The way we perceive ourselves influences our behaviour and our understanding of the actions of the others.

Acting plays an important role in extending the linguistic competence: In hardly any other area is so much emphasis put on a clear and loud pronunciation as in drama.
During the four years of the theatre project, the students were encouraged to become more independent and to take responsibility for their actions: they had to develop their own ideas for the performances, they had to write the texts for the characters (in groups) based on literary works, they had to decide the costumes and props and to actually manufacture them.

Using theatrical education one can trigger a positive process that combats aggression, social exclusion, racism and other negative phenomena. Acting can have a positive influence on conflict resolution ability, problem solving, teamwork and empathy. Introducing theatre pedagogy in school curriculum for undergraduates could have a positive effect on school life and life in general beyond the theatre area.

\section{Authors note:}

Mirona Stănescu, PhD., obtained her doctoral degree (Ph.D.) in Theatre Pedagogy and Educational Science at the University of Education Ludwigsburg, Germany. She is currently a senior lecturer in the Department of Pedagogy and Didactics in German Language, Faculty of Psychology and Educational Science, Babeş-Bolyai University, Cluj-Napoca. Her professional and research interests are theatre pedagogy, children's and youth literature, didactics of German as a second language.

Daniel Andronache, PhD., is a senior lecturer at the Department of Educational Sciences, Babeș-Bolyai University, Cluj-Napoca, Romania. He is graduate in Pedagogy, master's degree in School Counselling and Ph.D. in educational sciences. He made a research internship at the University of Vienna and also he was a postdoctoral researcher at at Babeș-Bolyai University. Daniel Andronache' main fields of interest include curriculum design, competence-based curriculum, systemic pedagogy and teacher training.

\section{References:}

Bandura, A. (1997). Self-efficacy: The exercise of control. New York: Freeman.

Blaskovich, J. \& Tomaka, J. (1991). Measures of self-esteem. Measures of Personality and Social Psychological Attitudes, 1,115-160.

Creswell, J. W. (2013). Qualitative inquiry and research design: Choosing among five approaches. 3rd ed. Thousand Oaks, CA: Sage. 
Czerny, G. (2004). Theaterpädagogik - Ein Ausbildungskonzept im Horizont personaler, ästhetischer und sozialer Dimension. Augsburg: Wißner Verlag

Deasy, R. J. (2002). Critical links: Learning in the arts and student academic and social development. Australian Journal of Music Education, 2, 5-16.

Goleman, D. 1998 Working with emotional intelligence. New York: Batam Books

Gresham, F.M, Sugai, G., \& Horner, R.H. (2001). Interpreting outcomes of social skills training for students with highincidence disabilities. Exceptional Children, 67, 331-344

Hentschel, U. (2000). Theaterspielen als ästhetische Bildung. Über einen Beitrag produktiven künstlerischen Gestaltens zur Selbstbildung. Weinheim: Deutscher Studien Verlag.

Jensen, E. (2001). Teaching with the brain in mind. Alexandria: Ed. Association for Supervision and Curriculum Development.

Jones, K. (2003). Education in Britain 1944 to the Present. Cambridge: Blackwell

Jurevičienè, M., Kaffemanienè, I., Ruškus, J. (2012). Concept and Structural Components of Social Skills. Ugdymas. Küno Kultūra. Sportas, 3 (86); 2012; 42-52.
Kim, H. S., Ko, D. (2007). Culture and self-expression. In C. Sedikides \& S. Spencer (Eds.). Frontiers of social psychology: The self (pp. 325-342). New York: Psychology Press.

Libet, J.M., Lewinsohn, P.M. (1973). Concept of social skill with spedal reference to the behaviour of depressed persons. Journal of Consulting and Clinical Psychology, 301-312.

Merrell, K. W., Gimpel, G. (2014). Social Skills of Children and Adolescents: Conceptualization, Assessment, Treatment. NY: Psychology Press

Scheller, Ingo (1998). Szenisches Spiel. Handbuch für die pädagogische Praxis. Berlin: Cornelsen Verlag Scriptor.

Scott, C. G. (2011). Student self-esteem and the school system: Perceptions and implications. Journal of Educational Research, 89(5), 286-293

Vaßen, F. (1997). Verkehrte Welt? Der Stellenwert von Ästhetik in Theaterwissenschaft und Theaterpädagogik. In: Belgrad, J. (Hg.). TheaterSpiele. Baltmannweiler: Schneider Verlag, S. 57-65

Yin, R. K. (2012). Applications of case study research. 3rd ed. Thousand Oaks, CA: Sage 